\title{
75. DEEP SEA DRILLING PROJECT SITES 417 AND 418: A PETROGENETIC SYNTHESIS
}

\author{
M. F. J. Flower, ${ }^{1}$ Smithsonian Institution, Museum of Natural History, Washington, D.C. \\ and \\ W. B. Bryan, Woods Hole Oceanographic Institution, Woods Hole, Massachusetts
}

\section{INTRODUCTION}

Detailed documentation of the chemical and physical properties of a thick segment of eruptive ocean crust has been made possible by the successful recovery of drilling samples at Sites 417 and 418 , and in particular, the unexpected freshness of basalts from Holes 417D and 418A. In this article, which deals with magmatic evolution at the Cretaceous spreading axis, we summarize chemical data for glass, whole-rock, and mineral samples. Shipboard analyses of whole-rock samples included most of the lithologic units, and provided a solid basis for the chemical stratigraphy (see Site Reports, this volume) and sampling for follow-up studies. The shore-based work throws further light on liquid magma variation trends, mineral-liquid disequilibrium phenomena, and the inferred phenocryst redistribution processes occurring before and after eruption to the sea floor. Comparison of these data to other well-studied submarine basalt suites suggests that these processes may be relevant to petrogenesis at most ocean ridges.

\section{"LIQUID" FRACTION}

Chemical data for fresh glass selvages (Byerly and Sinton; Thompson; both, this volume) give the compositions of the initially chilled, liquid fractions of partially crystalline lava eruptions. These compositions, plotted against depth, show marked stratigraphic discontinuities and delineate the chief eruptive magma batches making up the cored sections of crust. The uniformity of composition within these batches and their general lack of sedimentary or major breccia intercalations suggest that their compositions are determined by pre-eruptive fractionation. Several "chemical types" have been identified in Holes 417D and 418A (Byerly and Sinton, this volume), each representing liquidfraction compositional groups with a distinct stratigraphic identity. As defined by Byerly and Sinton, these "magma batches" comprise two or more chemical types within contiguous stratigraphic sequences, which may be interrelated by fractional crystallization from a common parent magma. These researchers also performed preliminary least-squares test for "liquid lines" developed by fractionation of various combinations of plagioclase (An70-90), olivine (Fo70-90), and clinopyroxene ( $\mathrm{W}_{40} \mathrm{En}_{50} \mathrm{Fs}_{10}$ ) to define possible variation trends within chemical batches. On the basis of such modeling, Byerly and Sinton conclude that two or more evolutionary trends exist at Holes 417D and 418A and have re-

\footnotetext{
'Present address: 25 Willes Road, London NW5, England.
}

fined the chemical stratigraphy according to the vertical relations of cogenetic magmas.

Evidence for disequilibrium between plagioclase and clinopyroxene megacrysts and their host glass (strongly embayed reaction morphology) is an important constraint for simple fractionation models and may reflect factors in addition to fractional crystallization. By comparison with other Atlantic DSDP sites, all compositions are relatively evolved, with $\mathrm{Mg} /\left(\mathrm{Mg}+\mathrm{Fe}^{+2}\right)$ ratios varying from 0.58 to +0.63 (in Hole 418A) and from 0.58 to +0.60 (in Hole 417D). No representatives of more primitive parent liquids are in evidence as chilled flow margins, but glass inclusions in plagioclase phenocrysts show $\mathrm{Mg} /\left(\mathrm{Mg}+\mathrm{Fe}^{+2}\right)$ ratios from 0.60 to $0.70, \mathrm{MgO}$ content from 8.5 to 12.3 wt. \%, $\mathrm{CaO}$ content from 10.6 to 12.3 wt. \%, and $\mathrm{Al}_{2} \mathrm{O}_{3}$ content from 14.0 to 9.6 wt. \%. In several cases, these compositions appear to lie off extrapolated cotectic liquid lines. Whether this is caused by post-inclusion contamination or crystallization, or to a more complex history of fractional crystallization and partial melting, is not clear. In view of current interest in evidence from trapped liquids, we shall review some petrogenetic implications of these data.

Average glass inclusion compositions (per associated glass selvage chemical type) are plotted in Figure 1 a-f in oxide variation diagrams, together with average chemical type compositions. Inclusion and selvage data for common chemical types (dashed lines) show some similarity to the broad trend, except for increasing or constant $\mathrm{Al}_{2} \mathrm{O}_{3}$ content, and decreasing $\mathrm{SiO}_{2}$ content, with decreasing $\mathrm{MgO}$ content. If this latter trend is caused by fractional crystallization, it indicates that plagioclase (the phase containing the inclusions) was not fractionating from the liquid; also, that pyroxene fractionation was probably the main control on the liquid variation. As many plagioclase phenocrysts are resorbed, it is possible that the glass inclusion-selvage curve indicates a "trapped,"' high-pressure fractionation trend, in which pyroxene precedes plagioclase at the liquidus. Rapid accession to a low-pressure environment would produce sharp changes in the phase equilibria, as recently shown by polybaric melting experiments of primitive ocean floor basalt samples (Bender et al., in press). Here, crystal-liquid fractionation would have started before the arrival of magmas in a high-level temporary chamber immediately beneath the rift.

\section{CRYSTALLINE FRACTION}

Assuming phenocrysts to be exclusively of pre-eruptive origin, their compositions and modal proportions in the lavas are crucial to evaluation of fractional crystallization 

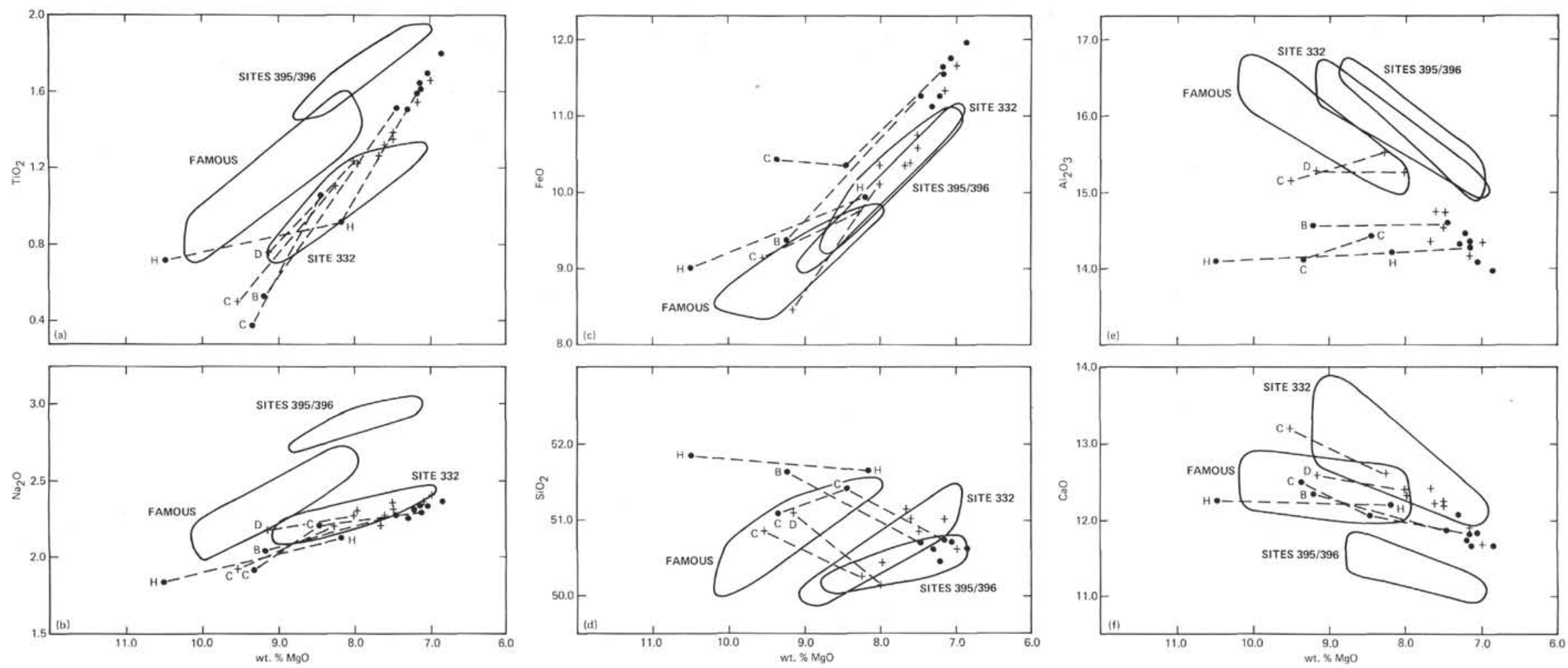

Figure 1. Plots of oxide versus $\mathrm{MgO}$ for average chemical type compositions, and for glass inclusions in plagioclase (data from Byerly and Sinton, this volume), shown in relation to glass trends for DSDP Sites 332 (Byerly and Wright, 1978), 395 (Melson, in press), 396 (Flower et al., 1978) and FAMOUS (Bryan and Moore, 1977). Symbols: $\bullet=417 D$ chemical types, $+=418 \mathrm{~A}$ chemical types. Dashed lines join glass selvage data points to glass inclusions that occur in the same chemical type stratigraphic interval (see Table 1). 
and other processes such as magma mixing. Phenocryst assemblages in the magmas of Sites 417 and 418 may be categorized as (spinel); plagioclase ( \pm spinel); plagioclase + olivine ( \pm spinel); plagioclase + olivine + plagioclase; plagioclase + clinopyroxene $( \pm$ magnetite); plagioclase $( \pm$ magnetite \pm clinopyroxene \pm apatite); (microphenocrysts in parentheses), apparently with decreasing temperature and increasing fractionation of the liquid phase (Sinton and Byerly, this volume). Evidence for reaction between clinopyroxene and spinel suggests these parageneses are determined, at least partly by liquid evolution between peritectic points ol-pl-sp and ol-pl-cpx which exist at low pressures ( $<3$ kbars) in the "natural" basalt system. However, modal mineral proportions may not be equivalent to an equilibrium assemblage, since phenocrysts have probably been redistributed differentially and subjected to changing equilibrium conditions (Bryan and Moore, 1977; Staudigel et al., this volume).

Mineral analyses by Sinton and Byerly (this volume) show that olivine phenocryst composition falls in the range Fo88-89.5. Clinopyroxene, more diverse in its crystal morphology, shows high $\mathrm{Mg} /\left(\mathrm{Mg}+\mathrm{Fe}^{+2}\right)$ ratios (up to 0.88 ) for early (embayed) generations. Later (euhedral) clinopyroxene has lower ratios $(0.7$ to 0.5$)$, and an increasing $\mathrm{TiO}_{2} / \mathrm{Al}_{2} \mathrm{O}_{3}$ ratio occurs as glomeroporphyritic clots with plagioclase, and is clearly cognate with the liquid fraction. Late-stage clinopyroxene is sub-calcic and coexists with pigeonite in some massive units. Plagioclase phenocrysts comprise the range An91-59 in composition and may exhibit embayment and complex zoning. Apatite and magnetite crystallization is marked by inflections in plagioclase and clinopyroxene compositional trends and occur at comparatively late (post-eruptive?) stages of lava consolidation. These phenocryst core compositions for olivine, clinopyroxene, and plagioclase are frequently too primitive to be cognate with the associated lava liquid fraction and must have equilibrated at earlier stages of fractionation. Thus crystal morphology and zoning patterns probably reflect complex and incomplete re-equilibration of the crystalliquid mix probably in response to reduced pressure and temperature as magma batches ascended. Phenocryst redistribution took place during temporary entrapment, and possible changes in liquid-fraction composition resulted from influx of new magma to the storage reservoir(s).

\section{PHENOCRYST REDISTRIBUTION}

Examination of whole-rock chemical data in relation to glass compositions led Flower et al., Staudigel et al., Emmermann and Puchelt, and Ui et al. (all, this volume) to interpret the variation and modal character of the lavas in terms of redistribution of phenocrysts at various stages of eruption and flowage.

Comparison of whole-rock compositions with those of associated glass indicates substantial post-eruptive phenocryst movement, possibly during outflow through extensive flow-tube networks. While plagioclase accumulation is almost universal, both olivine and clinopyroxene appear to be accumulated and fractionated out at this stage (Flower et al.; Staudigel, both, this volume) demonstrating this effect by contrasting two types of rock-glass oxide variation and comparing them with the observed modal mineralogy.
Post-eruptive phenocryst-liquid fractionation appears to be highly characteristic of ocean floor basalts, in strong contrast to subaerial eruptions where virtually no fractionation is in evidence over several kilometers of flowing lava (e.g., Kilauea, Wright et al., 1976). Convective phenocryst-liquid fractionation appears to be prevented during vesiculation (Wright et al., op. cit.). In a subaerial flow the loss of volatiles occurs during eruption and flow (Swanson and Fabbi, 1973), while in submarine environments degassing apparently does not occur - a consequence of the hydrostatic pressure allowing further fractionation of an erupted crystal-liquid mix. In contrast, it seems that posteruptive phenocryst formation is inhibited in submarine, but not in subaerial, lavas.

The bulk of phenocryst formation and differential movement clearly occurs in oceanic lavas before eruption, as they do in subaerial lavas. It appears that certain zones of the magma reservoir(s) tapped by eruptions may be enriched in plagioclase and mostly depleted in mafic phases. Bryan and Moore (1977) suggest that this accounts for the uneven phenocryst distribution in basalts of the FAMOUS area. Recent experimental work by Fujii and Kushiro (1977) suggests this is an example of simple gravitational differentiation in which plagioclase floats and mafic phases sink. From data on plagioclase and melt density, Fujii and Kushiro predict, and confirm experimentally, that calcic plagioclase $(\mathrm{An}>65)$ at low pressures $(<5 \mathrm{kbars})$ is denser than basaltic melt and sinks if suspended, whereas at higher pressures the melt density increases, thereby allowing suspended plagioclase to float. As many plagioclase cores in the magmas of Sites 417 and 418 are of approximately (An90) composition, it appears that crystallization and accumulation (by flotation) of plagioclase must have occurred at considerably higher pressures than is commonly assumed (ca. 1-2 kbars) for the principal stage of magma arrest. This evidence favors clinopyroxene-dominated fractionation at intermediate to high pressures. Even if plagioclase were crystallizing at below-liquidus temperatures, its accumulation and separation from liquidus mafic crystals could still result in exclusively plagioclase-phyric magma. This phenomenon was observed in lavas at Site 332, where plagioclase cumulates were associated with both high- and low$\mathrm{Al}_{2} \mathrm{O}_{3}$ liquid compositions, devoid of mafic phenocrysts.

\section{REGIONAL AND SECULAR VARIATION}

In Figure 1 a-f the oxide variation diagrams show comparisons of the trends of glass chemical type averages at Sites 417 and 418 with those at FAMOUS and at Sites 332 $\left(37^{\circ} \mathrm{N}\right), 395\left(22^{\circ} \mathrm{N}\right)$, and $396\left(22^{\circ} \mathrm{N}\right)$ on the Mid-Atlantic Ridge (MAR). Significant differences exist between the compositions at Sites 417 and 418 , and the trend of samples at $22^{\circ} \mathrm{N}$, which correlate by an approximate spreading flow line. For equivalent $\mathrm{MgO}$ contents, glasses at Sites 417 and 418 have lower $\mathrm{Na}_{2} \mathrm{O}, \mathrm{TiO}_{2}$ (although a higher $\mathrm{Na}_{2} \mathrm{O} / \mathrm{TiO}_{2}$ ratio), and $\mathrm{Al}_{2} \mathrm{O}_{3}$ contents, and higher $\mathrm{CaO}$ content than the $22^{\circ} \mathrm{N}$ glass, and, while showing great similarity to Site 332 glass, are still lower in $\mathrm{Al}_{2} \mathrm{O}_{3}$ content. It appears from Figure 1 (by analogy) that regional discrepancies of $\mathrm{Al}_{2} \mathrm{O}_{3}$ and $\mathrm{SiO}_{2}$ contents could also be explained in terms of a clinopyroxene component. Much of the variation could be the result of differential partial melting in equilibrium with a 
clinopyroxene-bearing mantle residue in the manner suggested by Byerly and Wright (1978). But regional tectonic variations may determine at any one site whether high- or low-pressure fractionation will be dominant.

The secular changes in basalt chemistry implied for $22^{\circ} \mathrm{N}$ are similar to those along the flow line of Leg 37 sites ( 15 to $3.5 \mathrm{~m} . \mathrm{y}$. old, Aumento, Melson, et al., 1977), and also to chemical gradients observed along the MAR axis by Melson et al. (1976) and Melson and O'Hearn (in press). However, considering lithophile element and radiogenic isotope data along crustal flow lines and the MAR axis (Schilling, 1976; Schilling et al., 1977; Hart et al., 1973), it is clear that fractional crystallization and variable partial melting are insufficient to explain these variations. Both types of regional transect show apparently random "decoupling" of lithophile elements on a wide scale, not compatible with simple inductive melt models involving the major peridotite phases (e.g., Pearce and Flower, 1977). Heterogeneity of the mantle is a possibility, in which different groups of lithophile elements have been selectively depleted from (and enriched in) the source. Bougault (1978) and Dmitriev (1978) have independently suggested two distinct mantle source compositions for the MAR, while Melson et al. (op cit.) and Melson (personal communication) propose a corresponding hiatus in basalt composition at $30^{\circ}$ to $35^{\circ} \mathrm{N}$.

Figure 2 a-c shows that abundance ratios at Sites 417 and 418 for $\mathrm{Hf} / \mathrm{Zr}, \mathrm{Ce} / \mathrm{Sm}, \mathrm{Ce} / \mathrm{Yb}$, and $\mathrm{Zr} / \mathrm{Y}$ are closest to the $22^{\circ} \mathrm{N}$ MAR compositions compared with Site 332 and FAMOUS compositions (except for Site 335 [the oldest at $\left.37^{\circ} \mathrm{N}\right]$ ). This is in surprising contrast to the major oxide data, in which basalt at Sites 417 and 418 more closely resembles Leg 37 and FAMOUS basalts, as discussed above. This seems to be yet another subtle example of major and trace element "decoupling."

\section{PRIMARY MAGMAS}

Postulates for magma mixing at ocean ridge axes (Rhodes and Dungan, 1978; O'Hara, 1977) infer that chemically diverse mid-ocean ridge basalt (MORB) liquids evolve from a high- $\mathrm{CaO}$ picrite liquid of uniform major-oxide composition. Is such a postulate corroborated by the regional and secular changes of glass composition shown in Figure 1?

Irvine (1977) has outlined a method for determining primary liquid compositions by extrapolating from the most primitive liquid composition of a lava series, to a composition with an appropriate $\mathrm{Mg} /\left(\mathrm{Mg}+\mathrm{Fe}^{+2}\right)$ [or $\mathrm{Ni} /(\mathrm{Mg}+$ $\left.\mathrm{Fe}^{+2}\right)$ ] ratio for equilibration with mantle residue assemblages. Peridotite xenoliths and mafic ocean-floor cumulate compositions define an olivine compositional range of Fo88-90, representing residual olivine compositions in the suboceanic mantle. Partitioning of $\mathrm{FeO}$ and $\mathrm{MgO}(\mathrm{K}$ $=0.31$ to +0.36 ; Irvine, op . cit .) between melts and olivine of these compositions requires a liquid having a $\mathrm{Mg} /(\mathrm{Mg}+$ $\mathrm{Fe}^{+2}$ ) ratio of 0.70 to 0.75 . Thus, glass inclusion composition No. 4 in Table 1 may represent a potential primary liquid. This, compared with glass inclusion compositions from Sites 332, 395, and 396, and Kilauea (Rhodes and Dungan, 1978; Irvine, op . cit.), shows a notably low $\mathrm{Al}_{2} \mathrm{O}_{3}$ and high $\mathrm{SiO}_{2}$ content. Ratios of lithophile elements and REE fractionation patterns for magmas at Sites 417 and 418 (Table 2) clearly indicate that all parent liquids at these sites are uniformly depleted, possibly reflecting a characteristic of the mantle source. This factor is still in dispute, however, as the mechanism of source depletion (apparent or real) has not yet been reconciled with radiogenic isotope variation.

Byerly and Sinton (op cit.) regard the discrepancies between separate magma batches at Sites 417 and 418 as evidence for multiple parent liquids, but also propose highpressure pyroxene fractionation, magma mixing, or continuous partial melting and eruption to explain discrepancies between glass inclusions and selvages. Rice et al. (this volume) also suggest magma mixing as a cause of the mineralliquid disequilibrium but not of the overall variation. While magma mixing may be an important factor during evolution of ocean ridge magma supply systems, it probably does not determine regional chemical differences unless feeder systems are highly characteristic for particular locations at the ridge axis. Unfortunately this aspect is at present little understood, and we need more information about the chronology and spatial characteristics of ridge axis volcanism.

\section{SUMMARY AND CONCLUSIONS}

In conclusion, we make the following broad inferences for the magmas at Sites 417 and 418:

1) Parent liquid compositions are typically depleted of lithophile elements, but have a distinctive major oxide chemistry that may reflect the pressure and temperature conditions of partial melting, in addition to the mantle source.

2) Fractionation in deep axial storage reservoirs involved massive density separation of calcic plagioclase (which floated) from clinopyroxene and olivine (which sank). Extrusive phenocryst assemblages thus may vary according to the level at which magma was tapped in the reservoir system.

3) Evidence for flotation of plagioclase and the "relict" pyroxene fractionation trend in glass inclusions suggest for the MAR higher pressure (or polybaric) fractionation regimes than so far accepted.

4) There is evidence for incomplete re-equilibration of partially crystalline magma in response to its rapid ascent and possible mixture with preceding batches, indicating (with 3) complex and incompletely closed systems of magma supply.

5) In contrast to subaerial lava flows, post-eruptive crystal-liquid fractionation (possibly in lava tube systems) is highly characteristic of oceanic lavas and contributes significantly to bulk chemical variation of consolidated lava units.

\section{REFERENCES}

Aumento, F., Melson, W. G., et al., 1977. Initial Reports of the Deep Sea Drilling Project, v. 37: Washington (U.S. Government Printing Office).

Bender, J. F., Hodges, F. N., and Bence A. E., in press. Petrogenesis of basalts from the project FAMOUS area: Experi-

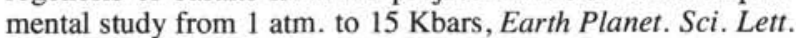

Bougault, H., 1978. Geochemistry of ocean crust: trace element fractional crystallization, partial melting and heterogeneity of the upper mantle from FAMOUS and IPOD basalts, Proc. 2 nd Ewing Symposium, March 1978, p. 6. (abstract).

Bryan, W. B. and Moore, J. G., 1977. Compositional variation of young basalts in the Mid-Atlantic Ridge rift valley near $36^{\circ} 49^{\prime}$ N, Geol. Soc. Am. Bull., v. 88 , p. $556-570$. 

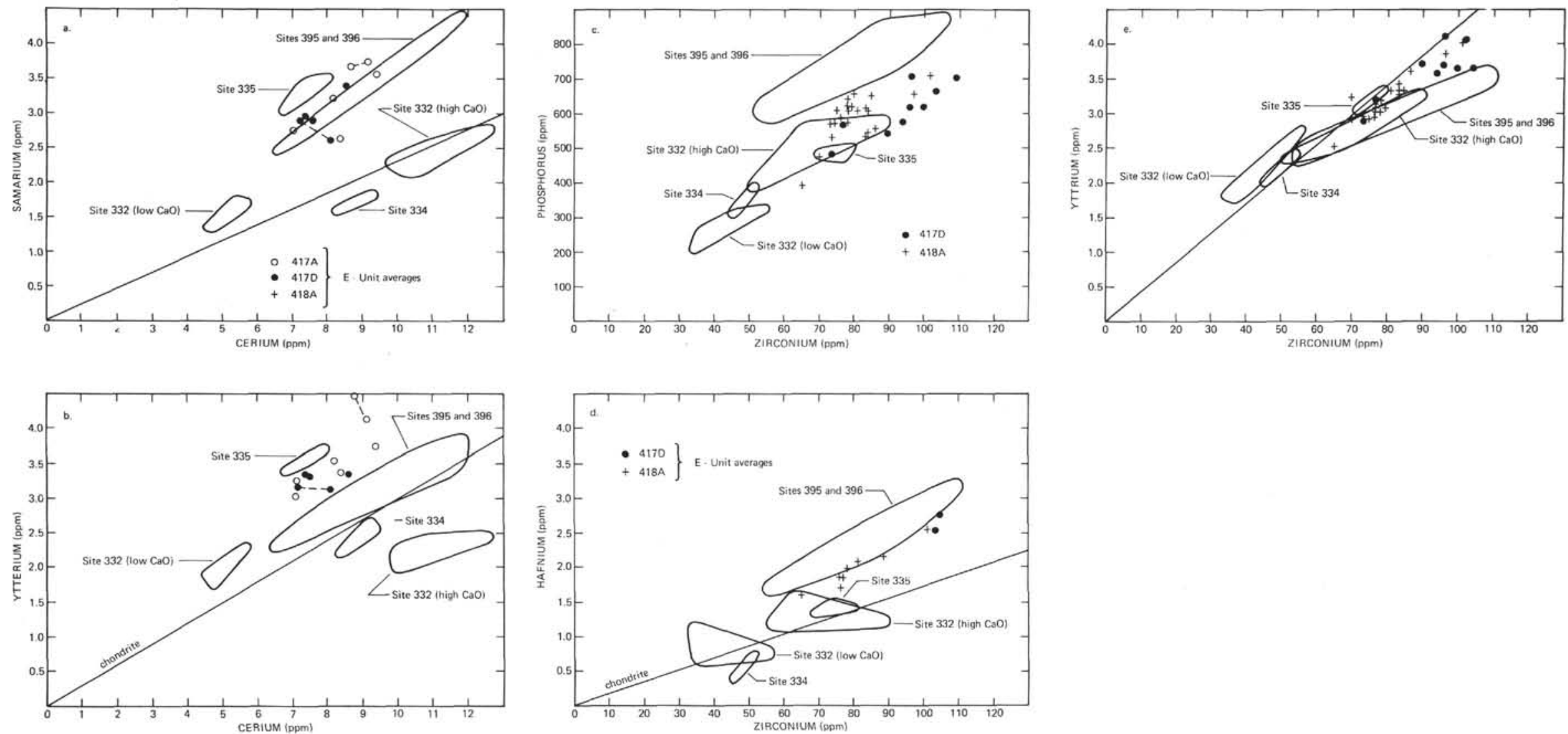

Figure 2. Plots of large-ion lithophile elements: $H f$ versus $\mathrm{Zr}$, Sm versus $\mathrm{Ce}, \mathrm{Yb}$ versus $\mathrm{Ce}, \mathrm{P}$ versus $\mathrm{Zr}$, and $Y$ versus $\mathrm{Zr}$; data averaged from Staudigel et al. (this volume), per eruptive unit as defined by Flower et al. (this volume), compared with those at Sites 332, 334, and 335 (data from Aumento, Melson, et al., 1977) and Site 396 (Flower et al., 1978). Symbols: $0=417 \mathrm{~A}$ samples, $\bullet=417 \mathrm{D}$ chemical type averages, $+=418 \mathrm{~A}$ chemical type averages. 
TABLE 1

Average Composition for Glass Inclusions in Plagioclase Megacrysts ${ }^{\mathrm{a}}$

\begin{tabular}{|c|c|c|c|c|c|c|c|}
\hline $\begin{array}{l}\text { Glass Inclusion } \\
\text { Composition No. }\end{array}$ & 1 & 2 & 3 & 4 & 5 & 6 & 7 \\
\hline Chemical Type & 417D-B & $-c_{1}$ & $-c_{2}$ & $-\mathrm{H}_{1}$ & $-\mathrm{H}_{2}$ & $418 \mathrm{~A}-\mathrm{C}$ & $-D$ \\
\hline $\begin{array}{l}\text { Symbols of } \\
\text { Figure } 1\end{array}$ & B & C & C & H & H & C & D \\
\hline $\mathrm{SiO}_{2}$ & 51.63 & 51.40 & 51.08 & 51.83 & 51.67 & 50.87 & 51.12 \\
\hline $\mathrm{Al}_{2} \mathrm{O}_{3}$ & 14.55 & 14.42 & 14.11 & 14.11 & 14.18 & 15.15 & 15.27 \\
\hline $\mathrm{FeO}^{\circ}$ & 9.38 & 10.33 & 10.44 & 9.00 & 9.96 & 9.12 & 8.41 \\
\hline $\mathrm{MgO}$ & 9.22 & 8.45 & 9.36 & 10.50 & 8.19 & 9.53 & 9.15 \\
\hline $\mathrm{CaO}$ & 12.37 & 12.05 & 12.49 & 12.26 & 12.20 & 13.21 & 12.51 \\
\hline $\mathrm{Na}_{2} \mathrm{O}$ & 2.04 & 2.21 & 1.93 & 1.84 & 2.14 & 1.93 & 2.18 \\
\hline $\mathrm{K}_{2} \mathrm{O}$ & 0.06 & 0.08 & 0.06 & 0.04 & 0.08 & 0.04 & 0.04 \\
\hline $\mathrm{TiO}_{2}$ & 0.55 & 1.08 & 0.37 & 0.74 & 0.92 & 0.49 & 0.77 \\
\hline $\mathrm{P}_{2} \mathrm{O}_{5}$ & 0.05 & 0.09 & 0.05 & 0.08 & 0.12 & 0.06 & 0.07 \\
\hline $\mathrm{Cr}_{2} \mathrm{O}_{3}$ & 0.07 & 0.06 & 0.07 & 0.11 & 0.03 & 0.08 & - \\
\hline Total & 99.92 & 100.17 & 99.96 & 100.51 & 99.49 & 100.48 & 99.52 \\
\hline n & 2 & 3 & 2 & 3 & 2 & 3 & 3 \\
\hline Mg-no. & 0.66 & 0.62 & 0.64 & 0.70 & 0.62 & 0.67 & 0.68 \\
\hline $\mathrm{CaO} / \mathrm{Al}_{2} \mathrm{O}_{3}$ & 0.850 & 0.836 & 0.885 & 0.869 & 0.860 & 0.872 & 0.819 \\
\hline
\end{tabular}

${ }^{\mathrm{a}}$ Data from Byerly and Sinton (this volume).

${ }^{\mathrm{b}}$ Total iron oxide as $\mathrm{FeO}$.

\section{TABLE 2}

Comparative Values of Lithophile Element Ratios for Atlantic Drill Sites and the "FAMOUS" Area

\begin{tabular}{lcccccc}
\hline \multicolumn{1}{c}{ Location } & $\begin{array}{c}\mathrm{Age} \\
(\mathrm{m} . \mathrm{y} .)\end{array}$ & $\mathrm{Ce} / \mathrm{Sm}$ & $\begin{array}{c}\mathrm{Na}_{2} \mathrm{O} / \mathrm{TiO}_{2} \\
\text { (average) }\end{array}$ & $\mathrm{Zr} / \mathrm{Y}$ & $\mathrm{P} / \mathrm{Zr}$ & $\begin{array}{c}\mathrm{Hr} / \mathrm{Zr} \\
\left(\times 10^{2}\right)\end{array}$ \\
\hline Sites 417 and 418 & 110 & $3.04-2.40$ & 2.05 & $2.19-2.92$ & $6.15-8.13$ & $2.0-2.6$ \\
Sites 395 and 396 & $10-13$ & $2.68-2.7$ & 1.71 & $2.22-3.24$ & $10.4-9.6$ & $2.4-3.2$ \\
FAMOUS & - & $4.0-6.0$ & 1.96 & - & - & \\
Site 332b & 3.4 & $4.88-4.2$ & 1.87 & $2.2-2.9$ & $6.4-8.3$ & $1.3-2.6$ \\
Site 332 & 3.4 & $3.85-3.14$ & 2.83 & $1.96-2.18$ & $5.7-7.5$ & $1.2-3.4$ \\
Site 334 & 9.4 & $5.36-4.87$ & 2.16 & $2.29-2.5$ & $6.7-7.8$ & $0.7-1.5$ \\
Site 335 & 13 & $2.28-2.22$ & 2.09 & $2.31-2.4$ & $6.0-7.9$ & $1.7-2.0$ \\
\hline
\end{tabular}

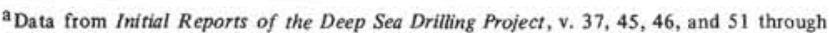
53 (this volume) and from Bryan et al., in press.

"High-CaO" magmas.

c"Low-CaO" magmas.

Bryan, W. B., Thompson, G., and Michael, P. J., in press. Compositional variation in a steady-stage zoned magma chamber: Mid-Atlantic Ridge at $36^{\circ} 50^{\prime} \mathrm{N}$, Tectonophysics.

Byerly, G. and Wright, T. L., 1978. Origin of major element chemical trends in DSDP Leg 37 basalts, Mid-Atlantic Ridge, J. Volcanol. Geotherm. Res., v. 3, p. 229-279.

Dmitriev, L., 1978. The primary melt of the oceanic tholeiite and the upper mantle composition, Proc. 2nd Ewing Symposium, March 1978, p. 11-12. (abstract).

Flower, M. F. J., Ohnmacht, W., Schmincke, H. U., Gibson, I. L., Robinson, P. T. and Parker, R., 1978. Petrology and geochemistry of basalts from Hole 396B, Leg 46. In Dmitriev, L., Heirtzler, J., et al., Initial Reports of the Deep Sea Drilling
Project, v. 46: Washington (U.S. Government Printing Office), p. 179-214.

Fujii, T. and Kushiro, L., 1977. Density, viscosity and compressibility of basaltic liquid at high pressures, Ann. Rept. Dir. Geophys. Lab., Carnegie Inst. Wash. Yearb., v. 76, p. 41-424.

Irvine, T. N., 1977. Definition of primitive liquid compositions for basic magmas, Ann. Rept. Dir. Geophys. Lab., Carnegie Inst. Wash. Yearb., v. 76, p. 454-461.

Hart, S. R., Schilling, J. G. and Powell, J. L., 1973. Basalts from Iceland and along the Reykjanes Ridge: $\mathrm{Sr}$ isotope geochemistry, Nature, v. 246, p. 104.

Melson, W. G., 1979. Chemical stratigraphy of Leg 45 basalts electron probe analyses of glasses. In Melson, W. G., Rabinowitz, P. D., et al. Initial Reports of the Deep Sea Drilling Project, v. 45: Washington (U.S. Government Printing Office), p. 507-512.

Melson, W. G., Vallier, T. L., Wright, T. L., Byerly, G., and Nelen, J., 1976. Chemical diversity of abyssal volcanic glass erupted along the Pacific, Atlantic and Indian Ocean sea-floor spreading centers. In Sutton, G., Manghnani, M. H., Moberly, R., (Eds.), The geophysics of the Pacific Ocean basin and its margins, Am. Geophys. Union Monograph, v. 20, p. 351-367.

Melson, W. G. and O'Hearn, T., in press. Recent to Miocene basaltic glass erupted along the Mid-Atlantic Ridge between $0-37^{\circ} \mathrm{N}$ : relationships between compositions and latitude. In Talwani, M. (Ed.), 2nd Ewing Volume, AGU.

O'Hara, M. J., 1977. Geochemical evolution during fractional crystallization of a periodically refilled magma chamber, $\mathrm{Na}$ ture, v. 266, p. 503-507.

Pearce, J. A. and Flower, M. F. J., 1977. The relative importance of petrogenetic variables in magma genesis at accreting plate margins: a preliminary investigation, J. Geol. Soc. London, v. 134 , p. $103-127$.

Rhodes, J. M. and Dungan, M. A., 1978. The evolution of ocean-ridge basaltic magmas, Proc. 2nd Ewing Symposium, March 1978 , p. $27-28$ (abstract).

Schilling, J. G., Kingsley, R. and Bergeron, M., 1977. Rare earth element abundances in DSDP Sites 332, 334 and 335, and inferences on the Azores mantle blob with time. In Aumento, F., Melson, W. G., et al., Initial Reports of the Deep Sea Drilling Project, v. 37: Washington (U.S Government Printing Office), p. 591-598.

Schilling, J.-G., 1975. Azores mantle blob; rare earth evidence. Earth Planet. Sci. Lett., v. 25, p. 103-115.

Swanson, J.G., 1975. Azores mantle blob; rare earth evidence. fountaining and flowage of basaltic lava at Kilauea Volcano, Hawaii, J. Res. U.S. Geol. Survey, v. 1, p. 649-658.

Wright, T. L., Peck, D. L., and Shaw, H. R., 1976. Kilauea lava lakes: Natural laboratories for study of cooling, crystallization and differentiation of basaltic magma, Am. Geophys. Union. Monograph, v. 19, p. 375-390. 